\title{
THRIPS (INSECTA: THYSANOPTERA) FROM VIEQUES ISLAND (PUERTO RICO)
}

A single species of thrips, Frankliniella insularis (Franklin), has been reported from Vieques; Leonard, ${ }^{1}$ Medina Gaud, ${ }^{2}$ and Wolcott. ${ }^{3}$ During a recent trip to this island, the author collected nine species not reported previously. Of these, Stomatothrips septenarius Hood has been reported only from Trinidad and St. Thomas in the West Indies. The following is a list of the species collected.

\section{SUBORDER TERDBRANTIA}

\section{Family Aeolothripidae}

1) Stomatothrips septenarius Hood; on leaf sheath of Panicum barbinode L.; Apr. 26, 1961.

\section{Family Thripidae}

2) Frankliniella insularis (Franklin); on flowers of Cajanus cajan (L.) Millsp. and Ipomoea stolonifera (Cyrill.) Poir; Nov. 26, 1962.

3) Frankliniella cephalica (Crawford); on flower of Ipomoea stolonifera Nov. 26, 1962.

4) Frankliniella difficilis Hood; on flower of Leucaena glauca (L.) Benth.; Nov. 26, 1962.

5) Plesiothrips perplexus (Beach); on flower of Dactyloctenium aegyptium (L.) Willd.; Nov. 26, 1962.

6) Heliothrips haemorrhoidalis (Bouch6); on leaf of Codiaeum variegatum (L.) Blume; Apr. 26, 1961.

7) Selenothrips rubrocinctus (Giard); on leaf of Terminalia catappa L.; Nov. 27, 1962.

8) Chirothrips mexicanus D.L. Crawford; on flower of Dactyloctenium aegyptium and inflorescence of Chloris inflata Link and Eleusine indica (L.) Gaertn; Nov. 26, 1962.

\section{SUBORDER TUBULIFERA}

\section{Family Phlaeothripidae}

9) Podothrips semiflavres Hood; on leaf sheath of Saccharum officinarum L.; Apr. 16, 1961.

1 Leonard, M. D., Thrips injurious to citrus and roses in Puerto Rico, J. Econ. Entomol. 25: 934-5, 1932.

Medina Gaud, S., The Thysanoptera of Puerto Rico, Agr. Expt. Sta., Univ. P.R. Tech. Paper 32, 157 pp., 1961.

Wolcott, G. N., The Insects of Puerto Rico, J. Agr. Univ. P. R. \$\& (1-4): 975 pp., 1948. 
272 JOURNAL OF AGRICUUTURE OF UNIVERSITY OF PDERTO RICO

10) Haplothrips gowdeyi (Franklin); on flower of Dactyloctenium aegyptium; Ipomoea stolonifera and inflorescence of Chloris inflata and Eleusine indica, April 16, 1961.

Silverio Medina Gaud

Department of Entomology 